\title{
Terapia genowa hemofilii - czy wkrótce będzie możliwe wyleczenie?
}

\section{Radosław Kaczmarek ${ }^{\bowtie}$}

Instytut Immunologii i Terapii Doświadczalnej im. Ludwika Hirszfelda PAN, Wrocław

Zakład Immunochemii, Instytut Immunologii i Terapii Doświadczalnej im. Ludwika Hirszfelda, Polska Akademia Nauk, ul. Weigla 12, 53-114 Wrocław; tel.: (071) 33711 72, e-mail: radoslaw.kaczmarek@iitd.pan.wroc.pl

Artykuł otrzymano 21 maja 2018 r.

Artykuł zaakceptowano 7 czerwca 2018 r.

Słowa kluczowe: hemofilia, terapia genowa, czynnik krzepnięcia VIII, czynnik krzepnięcia IX

Wykaz skrótów: AAV (ang. adeno-associated virus) - wirus towarzyszący adenowirusom; HIV (ang. human immunodeficiency virus) - ludzki wirus niedoboru odporności; HCV (ang. hepatitis C virus) - wirus zapalenia wątroby typu C; siRNA (ang. small interfering ribonucleic acid) mały interferujący kwas rybonukleinowy; PEG (ang. polyethylene glycol) - glikol polietylenowy; jm - jednostka międzynarodowa

Podziękowania: Praca została przygotowana w ramach projektu grantowego Opus DEC-2014/13/B/NZ6/00227 z Narodowego Centrum Nauki. Dziękuję prof. Joannie Kruszewskiej za zaproszenie do wygłoszenia wykładu na mini-sympozjum „Dzień Chorób Rzadkich: od eksperymentu do leczenia” i prof. Teresie Żołądek, która współorganizowała mini-sympozjum, za propozycję napisania niniejszej pracy.

\section{STRESZCZENIE}

$\mathbf{H}$

emofilia to osoczowa skaza krwotoczna, której przyczyną jest niedobór czynnika krzepnięcia krwi VIII (hemofilia typu A) lub rzadziej IX (hemofilia typu B). Geny kodujące czynniki krzepnięcia VIII i IX znajdują na chromosomie X, dlatego wrodzona hemofilia A i B dziedziczone są w sposób sprzężony z płcią. Głównym objawem choroby są częste samoistne krwawienia do stawów, które powodują artropatię hemofilową. Hemofilię leczono początkowo za pomocą przetaczania pełnej krwi. Później do leczenia wprowadzono preparaty osocza. Dużym przełomem w leczeniu było zastosowanie krioprecypitatu a następnie liofilizowanych koncentratów czynników krzepnięcia wytwarzanych z osocza, co pozwoliło na domowe leczenie i profilaktykę krwawień. Zmiany te znacznie zwiększyły skuteczność leczenia i jakość życia pacjentów. Od początku lat 1990 stosuje się koncentraty rekombinowanych czynników krzepnięcia otrzymywanych w liniach komórkowych. Dziś główne wyzwania w leczeniu hemofilii to konieczność częstych dożylnych wkłuć $w$ celu zapobiegania krwawieniom i pojawianie się u części chorych neutralizujących przeciwciał rozpoznających czynniki krzepnięcia. W ostatnich latach zatwierdzono kilka rekombinowanych czynników krzepnięcia o wydłużonym okresie półtrwania. Trwają też zaawansowane próby kliniczne leków niezawierających czynników krzepnięcia (np. emicizumab: dwuswoiste przeciwciało naśladujące funkcje czynnika VIII; fitusiran, czyli siRNA hamujący syntezę antytrombiny III) oraz terapii genowych za pomocą wirusowych wektorów AAV.

\section{WPROWADZENIE}

Hemofilia jest osoczową skazą krwotoczną, najczęściej wrodzoną. Hemofilia A (niedobór czynnika krzepnięcia krwi VIII) występuje z częstością 1:5000 urodzeń, z kolei hemofilia B (niedobór czynnika IX) pojawia się z częstością 1:30000 urodzeń [1]. Niedobór czynnika krzepnięcia XI nazywa się czasami hemofilią C, ale skaza ta występuje jeszcze rzadziej i ma inny obraz kliniczny niż hemofilie A i B. Głównym objawem hemofilii A i B są nawracające krwawienia do stawów, które powodują artropatię hemofilową: zanik szpary stawowej, ograniczenie ruchomości, ubytek masy mięśniowej i przewlekły ból [2].

Czynniki VIII i IX odgrywają ściśle związane ze sobą role w układzie krzepnięcia krwi: czynnik VIII jest białkowym kofaktorem czynnika IX. Z kolei czynnik IX jest proteazą serynową, która w kompleksie z czynnikiem VIII aktywuje czynnik krzepnięcia X. Docelową rolą osoczowych składników układu krzepnięcia, w tym kompleksu czynników VIII i IX, jest wzmocnienie wytwarzania trombiny, co jest kluczowe dla powstania prawidłowego skrzepu. W zależności od stopnia niedoboru czynnika VIII lub IX, objawy hemofilii mają różne nasilenie (Tab. 1). W ciężkiej postaci hemofilii może dochodzić do samoistnych krwawień, bez wyraźnej przyczyny [3].

Geny kodujące czynniki VIII (F8) i IX (F9) znajdują się w chromosomie X, dlatego wrodzona hemofilia jest dziedziczona w sposób sprzężony z płcią i chorują na nią przede wszystkim mężczyźni. W około połowie przypadków hemofilii A przyczyną choroby jest inwersja intronu $22 \mathrm{w}$ genie F8. Za hemofilię B odpowiadają głównie mutacje zmiany sensu w genie F9 [4-6]. W rzadkich przypadkach kobiety będące nosicielkami mogą mieć pełnoobjawową hemofilię wskutek inaktywacji chromosomu X z prawidłowym genem F8 lub F9 [7].

Czynnik IX jest syntezowany w hepatocytach, podobnie jak większość innych czynników krzepnięcia. Długo uważano, że hepatocyty produkują także czynnik VIII, ponieważ przeszczepienie wątroby od zdrowej osoby choremu na hemofilię podnosi aktywność czynnika VIII w osoczu chorego do prawidłowego poziomu, jednak niedawno wykazano, że za syntezę czynnika VIII odpowiedzialne są komórki śródbłonkowe [8-10]. 
Tabela 1. Aktywność czynnika VIII lub IX w różnych postaciach hemofilii.

\begin{tabular}{|c|c|c|}
\hline $\begin{array}{l}\text { Aktywność czynnika } \\
\text { VIII lub IX (jm/ml) w } \\
\text { osoczu }\end{array}$ & Postać hemofilii & Objawy \\
\hline $0,5-1,5(50-150 \%)$ & nie dotyczy (zakres prawidłowy) & nie dotyczy \\
\hline $0,05-0,5(5-50 \%)$ & łagodna & nadmierne krwawienia po silnych urazach i zabiegach chirurgicznych \\
\hline $0,01-0,05(1-5 \%)$ & umiarkowana & $\begin{array}{l}\text { krwawienia do stawów i mięśni po łagodnych urazach, nadmierne krwawienia po zabiegach } \\
\text { chirurgicznych }\end{array}$ \\
\hline $0,00-0,01(0-1 \%)$ & ciężka & $\begin{array}{l}\text { samoistne krwawienia do stawów i mięśni, nadmierne krwawienia po łagodnych urazach i } \\
\text { zabiegach chirurgicznych }\end{array}$ \\
\hline
\end{tabular}

\section{HISTORIA LECZENIA CHORYCH NA HEMOFILIĘ}

Pierwsze skuteczne próby leczenia chorych na hemofilię podejmowano już $\mathrm{w}$ połowie XIX wieku: polegały one na przetaczaniu pełnej krwi [11]. Gdy w latach 30-tych XX wieku wykazano ostatecznie, że przyczyną hemofilii jest brak jednego ze składników białkowych osocza, zaczęto leczyć krwawienia u chorych na hemofilię za pomocą przetaczania osocza $[12,13]$. Dużym przełomem było odkrycie, że frakcja wytrąconych białek powstająca podczas rozmrażania osocza (krioprecypitat) wykazuje dużą aktywność czynnika VIII [14]. Preparat zwiększył skuteczność leczenia hemofilii A, ponieważ pozwalał na przetoczenie leczniczej dawki czynnika VIII w mniejszej objętości niż w przypadku osocza. Kolejnym przełomem było otrzymanie liofilizowanych koncentratów czynników VIII i IX. Preparaty te wciąż są stosowane $\mathrm{w}$ leczeniu chorych na hemofilię i pozwalają skutecznie leczyć i zapobiegać krwawieniom.

Wytwarzanie osoczopochodnych liofilizowanych koncentratów czynników krzepnięcia obejmuje mieszanie osocza pobranego od nawet 120000 dawców. Do 1985 roku w produkcji tych leków nie stosowano metod inaktywacji i usuwania wirusów, dlatego ich przyjmowanie było obarczone dużym ryzykiem zakażenia ludzkim wirusem niedoboru odporności (HIV, ang. human immunodeficiency virus) i zapalenia wątroby typu C (HCV, ang. hepatitis C virus) [1517]. Dzisiejsze metody produkcyjne znacznie ograniczają ryzyko przeniesienia czynników zakaźnych przez leki osoczopochodne, jednak istnieje ryzyko pojawienia się nowego czynnika zakaźnego, niewrażliwego na obecnie stosowane środki bezpieczeństwa [18].

W latach 90. XX wieku wdrożono koncentraty rekombinowanych czynników krzepnięcia VIII i IX, produkowane za pomocą hodowli zwierzęcych komórek transfekowanych wektorami kodującymi te czynniki. W niektórych krajach całkowicie zastąpiono nimi koncentraty osoczopochodne. Koncentraty czynników krzepnięcia VIII i IX wciąż są lekami z wyboru w leczeniu i zapobieganiu krwawieniom u chorych na hemofilię $[1,3,19]$.

Standardem leczenia jest dziś zapobieganie krwawieniom przez samodzielne profilaktyczne podawanie koncentratów czynników krzepnięcia $\mathrm{w}$ domu pacjenta $\mathrm{w}$ takich odstępach, które pozwalają na utrzymanie aktywności czynnika w osoczu powyżej $0,01 \mathrm{jm} / \mathrm{ml}(1 \%)$. Takie postępowanie zapobiega większości samoistnych krwawień. Po- nieważ okres półtrwania czynników VIII i IX przeciętnie wynosi odpowiednio 12 i 24 godziny, skuteczne leczenie profilaktyczne wymaga dożylnego podawania leków dwa (czynnik IX) lub trzy (czynnik VIII) razy w tygodniu [1].

\section{DZISIEJSZE WYZWANIA W LECZENIU CHORYCH NA HEMOFILIĘ}

Najpoważniejszym powikłaniem leczenia hemofilii jest dziś pojawienie się neutralizujących przeciwciał rozpoznających czynnik VIII lub IX, które mogą całkowicie uniemożliwiać leczenie substytucyjne [20]. Inne aktualne problemy leczenia chorych na hemofilię to trudny dostęp żylny u części pacjentów, który nie sprzyja prawidłowemu leczeniu profilaktycznemu, oraz zmienny poziom zabezpieczenia przed krwawieniem w czasie pomiędzy dawkami leków, co nie pozwala na zapobieganie wszystkim krwawieniom i zmusza pacjentów do częściowego ograniczania fizycznej aktywności. Liczne nowe leki wchodzące właśnie na rynek leczniczy lub będące $\mathrm{w}$ zaawansowanych próbach klinicznych mogą ułatwić leczenie chorych na hemofilię, w tym pacjentów, u których pojawiły się przeciwciała neutralizujące czynniki krzepnięcia (Ryc. 1) [21-23].

\section{NOWE GENERACJE LEKÓW}

W ostatnich czterech latach pojawiło się kilka rekombinowanych czynników krzepnięcia VIII i IX o przedłużonym okresie półtrwania. Kilka kolejnych leków tej klasy znajduje się w fazie III badań klinicznych. Przedłużenie okresu półtrwania uzyskano przez fuzję z innym białkiem (np. fragmentem Fc immunoglobuliny $\mathrm{G}$ lub albuminą), sprzężenie z PEG (glikol polietylenowy; ang. polyethylene glycol) lub wprowadzenie zmian $\mathrm{w}$ sekwencji aminokwasowej czynników krzepnięcia. W ten sposób około 1,5-krotnie przedłużono okres półtrwania czynnika VIII i nawet 5-krotnie przedłużono okres półtrwania czynnika IX. Pozwala to na utrzymanie aktywności czynnika krzepnięcia w osoczu powyżej $0,01 \mathrm{jm} / \mathrm{ml}(1 \%)$ mimo większych odstępów pomiędzy dawkami niż w przypadku standardowych leków lub na podniesienie minimalnej aktywności pomiędzy dawkami przy niezmienionej częstości podawania i w ten sposób na skuteczniejsze zabezpieczenie chorych przed krwawieniami (Ryc. 1) [17].

Trwają też zaawansowane próby kliniczne leków do terapii niesubstytucyjnych, które można podawać podskórnie zarówno chorym na niepowikłaną hemofilię jak i pacjentom 


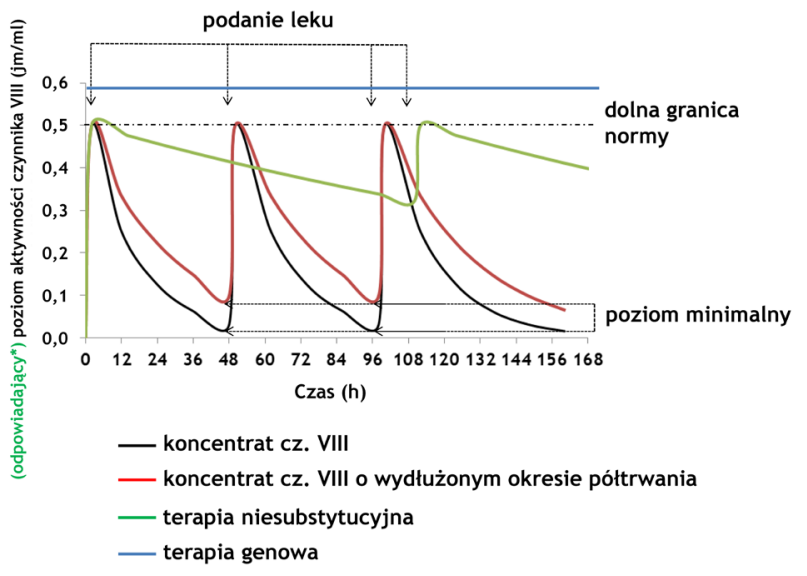

"Korekcje zaburzenia krzepnięcia krwi pod wplywem podania leku można oceniać za pomocą pomiaru ilości wytwarzanej trómbiny. Na podstawie krzywej kalibracyjnej mozna oszacowac jakiemu poziomowi czynnika VII
odpowiada ilośc trombiny wytwarzanej po podaniu leku niesubstytucyinego (np. emicizumabu, Tabela 2)

Rycina 1. Porównanie właściwości farmakokinetycznych koncentratów czynników krzepnięcia o standardowym i przedłużonym okresie półtrwania, terapii niesubstytucyjnych oraz terapii genowej (symulacja). Okres półtrwania czynnika VIII wynosi przeciętnie 12 godzin (czarna linia). Dłużej działające czynniki VIII mają przeciętnie 1,5-krotnie wydłużony okresie półtrwania, co pozwala na większe przerwy między dawkami lub uzyskanie większego minimalnego poziomu czynnika VIII między dawkami przy niezmienionej częstości podawania i w ten sposób lepszej ochrony przed krwawieniami (czerwona linia). Leki do terapii niesubstytucyjnej działają o wiele dłużej, dzięki czemu mogą być dawkowane znacznie rzadziej i utrzymywać między dawkami zbliżony do prawidłowego poziom krzepliwości (zielona linia). Terapia genowa pozwala na trwałe podniesienie poziomu czynnika VIII do prawidłowego zakresu (niebieska linia).

z neutralizującymi przeciwciałami rozpoznającymi czynniki krzepnięcia (Tab. 2). Ponadto kolejne dawki tych leków mogą być podawane z jeszcze mniejszą częstością niż dłużej działające czynniki krzepnięcia i jeszcze lepiej chronić przed krwawieniami (Ryc. 1) [17,24,25].

\section{TERAPIA GENOWA HEMOFILII}

Możliwość leczenia chorych na hemofilię za pomocą terapii genowej jest badana od ponad 20 lat. Na początku badań nad terapią wydawało się, że hemofilia powinna względnie łatwo poddawać się leczeniu tą metodą, ponieważ jest to ściśle zdefiniowana choroba monogenowa a zakresy prawidłowych aktywności czynników krzepnięcia VIII i IX są stosunkowo szerokie (Tab. 1). Jednak pierwsze udane doświadczenia na zwierzętach z hemofilią były trudne do powtórzenia w próbach klinicznych [26-29]. Pierwsze badania kliniczne przedwcześnie wstrzymywano z powodu łagodnych objawów niepożądanych, bądź niskiego lub przemijającego poziomu ekspresji transgenu [30,31]. Rozwój terapii genowej hemofilii opóźniały też niepowodzenia terapii genowych innych chorób. Ponadto w środowisku pacjentów z hemofilią bezpieczeństwo leczenia stało się silnym tabu po wybuchu epidemii HIV i HCV, dlatego próby kliniczne terapii genowej podejmowano z tym większą ostrożnością.
Obecnie rozpoczyna się trzecia faza kilku badań klinicznych terapii genowej hemofilii (dwie z nich dotyczą hemofilii B, jedna dotyczy hemofilii A). Niedawno opublikowane wyniki otrzymane podczas drugiej fazy tych badań wskazują, że za pomocą terapii genowej będzie można fizjologicznie wyleczyć hemofilię. W badaniach tych u siedmiu pacjentów (sześciu $\mathrm{z}$ hemofilią A i jednego $\mathrm{z}$ hemofilią $\mathrm{B}$ ) udało się podnieść aktywność czynnika krzepnięcia VIII lub IX w osoczu do prawidłowego zakresu. Prawidłowa aktywność czynników VIII i IX utrzymywała się na niezmienionym poziomie po 52 tygodniach od podania transgenu [3234]. Wszyscy ci pacjenci zaprzestali terapii substytucyjnej i nie wystąpiło $\mathrm{u}$ nich $\mathrm{w}$ tym czasie ani jedno krwawienie.

W przypadku wszystkich trzech badań klinicznych terapia genowa polega na jednorazowym dożylnym podaniu hepatotropowych wektorów wirusowych kodujących czynniki krzepnięcia VIII lub IX. Jako wektory wykorzystuje się różne serotypy wirusa towarzyszącego adenowirusom (AAV, ang. adeno-associated virus). AAV są niepatogennymi wirusami z rodziny parwowirusów. Wektory AAV wprowadzają transgeny do hepatocytów, gdzie ulegają one episomalnej ekspresji. Kapsydy AAV mogą pomieścić DNA o wielkości maksymalnie 4,5 tysiąca par zasad, co wymagało znacznej modyfikacji transgenu zastosowanego $\mathrm{w}$ terapii hemofilii A (sekwencja kodująca czynnik VIII ma ponad 9 tysięcy par zasad). Przede wszystkim sekwencja kodująca czynnik VIII w transgenie została pozbawiona fragmentu kodującego domenę B, która nie jest potrzebna do jego aktywności prokoagulacyjnej. Z kolei w terapii hemofilii B zastosowano gen kodujący czynnik IX z mutacją powodującą podstawienie aminokwasowe p.R338L [24]. Muteina ta wykazuje około 8-krotnie zwiększoną aktywność enzymatyczną. Umożliwia to podawanie mniejszej dawki wektora kodującego czynnik IX, co zmniejsza ryzyko komórkowej odpowiedzi odpornościowej na wektor. Ten wariant czynnika IX nazwano padewskim, ponieważ mutację powodującą podstawienie p.R338L odkryto w szpitalu uniwersyteckim w Padwie u pacjenta cierpiącego na wrodzoną trombofilię [35]. Wektory AAV do terapii genowej wytwarza się w hodowlach ludzkich zarodkowych komórek nerki (HEK293) oraz komórek jajnikowych owada z rzędu motyli, Spodoptera frugiperda (Sf9 i pokrewne klony tej linii) [32-34,36].

$\mathrm{Na}$ razie trudno ocenić jak długo będzie się utrzymywało lecznicze działanie terapii genowej. Pierwsi pacjenci, u których udało się osiągnąć trwały wzrost aktywności czynnika krzepnięcia, otrzymali leczniczy wektor w 2010 roku i wciąż utrzymuje się u nich ekspresja transgenu [37]. U żadnego z pacjentów, którzy otrzymali leczniczy wektor nie pojawiły się przeciwciała rozpoznające czynniki krzepnięcia kodowane przez transgen, mimo że niektórzy byli obarczeni genetycznie zwiększonym ryzykiem wytworze-

Tabela 2. Leki do terapii niesubstytucyjnej w zaawansowanych badaniach klinicznych.

\begin{tabular}{|c|c|c|}
\hline $\begin{array}{l}\text { Nazwa } \\
\text { leku }\end{array}$ & Struktura i mechanizm działania & Zastosowanie \\
\hline emicizumab & monoklonalne dwuswoiste przeciwciało rozpoznające czynniki IX i X krzepnięcia (naśladuje funkcję czynnika VIII) & hemofilia A \\
\hline anty-TFPI & monoklonalne przeciwciało rozpoznające inhibitor szlaku czynnika tkankowego (TFPI, endogenny inhibitor krzepnięcia krwi) & hemofilia A i B \\
\hline fitusiran & mały interferujący RNA, który obniża poziom transkryptu kodującego antytrombinę III (endogenny inhibitor krzepnięcia krwi) & hemofilia A i B \\
\hline
\end{tabular}


nia takiej odpowiedzi. Wątroba, jako środowisko ekspresji transgenu, może sprzyjać tolerancji odpornościowej [38]. Z punktu widzenia bezpieczeństwa terapii istnieje teoretyczne ryzyko onkogenezy w wyniku integracji DNA zawierającego transgen do genomu komórki gospodarza, chociaż wirusy AAV ulegają integracji w niewielkim stopniu a ich geny ulegają ekspresji episomalnej [24]. Poza tym potencjalną przeszkodą $\mathrm{w}$ rozpowszechnieniu terapii może być częste występowanie $\mathrm{w}$ populacji przeciwciał rozpoznających białka kapsydowe różnych serotypów AAV. Obecność takich przeciwciał u pacjentów, kandydatów do terapii jest kryterium wykluczającym $\mathrm{w}$ większości prowadzonych prób klinicznych. Ponadto u uczestników badań klinicznych przeciwciała te pojawiają się w odpowiedzi na podany wektor, co uniemożliwia ewentualne powtórzenie terapii za pomocą wektora $\mathrm{z}$ takim samym serotypem [33].

\section{PODSUMOWANIE}

Mimo licznych pytań, które na razie pozostają bez odpowiedzi, terapia genowa hemofilii za pomocą wektorów AAV jest obiecującą metodą leczenia, która może pozwalać na przynajmniej tymczasowe wyleczenie pod względem działania układu krzepnięcia. Zagadnienie docelowego poziomu czynnika krzepnięcia u pacjenta poddanego terapii genowej jest obecnie przedmiotem licznych dyskusji między klinicystami, instytucjami regulatorowymi (FDA, ang. Food and Drug Administration; EMA, ang. European Medicines Agency) oraz organizacjami pacjentów. Ponieważ stosunkowo niewielkie podniesienie poziomu czynnika krzepnięcia u pacjenta z ciężką postacią hemofilii łagodzi najcięższe objawy choroby, część ekspertów uważa, że nie jest potrzebne podwyższanie poziomu czynnika do prawidłowego zakresu. Z kolei wielu pacjentów właśnie tego („wyleczenia") oczekuje od terapii. Rozbieżność ta wynika z tego, że skuteczność standardowych terapii oceniano do tej pory na podstawie zmian w liczbie krwawień, które wystąpiły u pacjenta w ciągu roku. Leczenie profilaktyczne na ogół powoduje, że liczba krwawień maleje z kilkudziesięciu do kilku (u części pacjentów do zera) rocznie. Terapia genowa także powoduje, że krwawienia przestają występować, zatem porównanie skuteczności terapii genowej z profilaktycznym leczeniem koncentratami tylko w oparciu o ten wskaźnik pozornie wskazuje, że terapia genowa nie jest lepsza od leczenia profilaktycznego. Z kolei pacjenci zgłaszają dodatkowe (i trudniejsze do uchwycenia) zmiany w jakości życia związane z większym poziomem czynnika krzepnięcia, np. złagodzenie przewlekłego bólu stawów i możliwość podejmowania bardziej intensywnej aktywności fizycznej. Takich obserwacji dokonują szczególnie pacjenci, których poddano przeszczepieniu wątroby (co powoduje zwiększenie poziomu czynnika krzepnięcia do prawidłowych wartości). Może to być związane z eliminacją mikrokrwawień, które mogą występować przy nieprawidłowym poziomie czynnika krzepnięcia bez ostrych objawów i z czasem powodować uszkodzenie stawów. Innym pośrednim dowodem na to, że możemy mieć do czynienia z takim zjawiskiem, jest występowanie łagodnej artropatii u nosicielek hemofilii z poziomem czynnika krzepnięcia zbliżonym do prawidłowego [39]. Dlatego zmiany w liczbie krwawień w ciągu roku są niewystarczające do rzetelnej oceny skuteczności terapii genowej. W związku tym pojawił się postulat, żeby zwięk- szenie poziomu czynnika krzepnięcia po terapii genowej, $\mathrm{w}$ połączeniu z dodatkowymi wskaźnikami (np. nasilenie przewlekłego bólu stawów), było głównym wyznacznikiem jej skuteczności [40]. Niezależnie od wyników tych sporów, jeśli najbardziej zaawansowane obecnie próby kliniczne zakończą się powodzeniem, terapia genowa zrewolucjonizuje leczenie pacjentów z hemofilią.

\section{PIŚMIENNICTWO}

1. Zimmerman B, Valentino LA (2013) Hemophilia: In Review. Pediatr Rev 34: 289-295

2. Zawilska K, Chojnowski K, Klukowska A, Letowska M, Mital A, Musial J, Podolak-Dawidziak M, Undas A, Windyga J, Zdziarska J (2011) Polish guidelines for the management of rare clotting factor deficiencies. Hematologia 2: 303-310

3. Zdziarska J, Chojnowski K, Klukowska A, Łetowska M, Mital A, Podolak-Dawidziak M, Windyga J, Zawilska K, Working Group on Hemostasis of the Polish Society of Hematologists and Transfusiologists (2009) Therapeutic properties and safety of recombinant factor VIII and factor IX. Pol Arch Med Wewn 119: 403-409

4. Sawecka J, Skulimowska J, Windyga J, Lopaciuk S, Kościelak J (2005) Prevalence of the intron 22 inversion of the factor VIII gene and inhibitor development in Polish patients with severe hemophilia A. Arch Immunol Ther Exp (Warsz) 53: 352-356

5. Bowen DJ (2002) Haemophilia A and haemophilia B: molecular insights. Mol Pathol 55: 1-18

6. Peyvandi F, Kunicki T, Lillicrap D (2013) Genetic sequence analysis of inherited bleeding diseases. Blood 122: 3423-3431

7. Zheng J, Ma W, Xie B, Zhu M, Zhang C, Li J, Wang Y, Wang M, Jin Y (2015) Severe female hemophilia A patient caused by a nonsense mutation (p.Gln1686X) of F8 gene combined with skewed X-chromosome inactivation. Blood Coagul Fibrinolysis 26: 977-978

8. Everett LA, Cleuren ACA, Khoriaty RN, Ginsburg D (2014) Murine coagulation factor VIII is synthesized in endothelial cells. Blood 123: 3697-3705

9. Fahs SA, Hille MT, Shi Q, Weiler H, Montgomery RR (2014) A conditional knockout mouse model reveals endothelial cells as the principal and possibly exclusive source of plasma factor VIII. Blood 123: 3706 3713

10. Tuddenham E (2014) In search of the source of factor VIII. Blood 123: 3691-3691

11. Lane S (1840) Haemorrhagic diathesis. Successful transfusion of blood. Lancet 35: 185-188

12. Patek AJ, Taylor FHL (1937) Hemophilia. II. Some properties of substance obtained from normal human plasma effective in accelerating the coagulation of hemophilic blood. J Clin Invest 16: 113-124

13. Lozner EL, Kark R, Taylor FHL (1939) The coagulation defect in hemophilia: the clot promoting activity in hemophilia of berkefelded normal human plasma free from fibrinogen and prothrombin. J Clin Invest 18: 603-608

14. Pool JG, Gershgold EJ, Pappenhagen AR (1964) High-potency antihaemophilic factor concentrate prepared from cryoglobulin precipitate. Nature 203: 312

15. Evatt BL (2006) The tragic history of AIDS in the hemophilia population, 1982-1984. J Thromb Haemost 4: 2295-2301

16. Makris M, Konkle BA (2017) Hepatitis C in haemophilia: time for treatment for all. Haemophilia 23: 180-181

17. Pierce GF, Pipe SW (2017) A cornucopia of therapies under study for hemophilia. Mol Ther 25: 2429-2430

18. Norja P, Lassila R, Makris M (2012) Parvovirus transmission by blood products - a cause for concern? Br J Haematol 159: 385-393

19. Mannucci PM (2008) Back to the future: a recent history of haemophilia treatment. Haemophilia 14 Suppl 3: 10-8

20. Benson G, Auerswald G, Elezović I, Lambert T, Ljung R, Morfini M, Remor E, Šalek SZ (2012) Immune tolerance induction in patients with 
severe hemophilia with inhibitors: Expert panel views and recommendations for clinical practice. Eur J Haematol 88: 371-379

21. Fischer K, Poonnoose P, Dunn AL, et al (2016) Choosing outcome assessment tools in haemophilia care and research: a multidisciplinary perspective. Haemophilia 1-14

22. Makris M (2016) Hemophilia A treatment: disruptive technology ahead the. 127: 1623-1625

23. Kaufman RJ, Powell JS (2013) Molecular approaches for improved clotting factors for hemophilia. Blood 122: 3568-3574

24. Ling G, Nathwani AC, Tuddenham EGD (2018) Recent advances in developing specific therapies for haemophilia. Br J Haematol 181: 161 172

25. Franchini M, Mannucci PM (2018) Non-factor replacement therapy for haemophilia: a current update. Blood Transfus 1-5

26. Herzog RW, Hagstrom JN, Kung SH, Tai SJ, Wilson JM, Fisher KJ, High KA (1997) Stable gene transfer and expression of human blood coagulation factor IX after intramuscular injection of recombinant adeno-associated virus. Proc Natl Acad Sci USA 94: 5804-5809

27. Kay MA, Manno CS, Ragni M V, et al (2000) Evidence for gene transfer and expression of factor IX in haemophilia B patients treated with an AAV vector. Nat Genet 24: 257-261

28. Herzog RW, Yang EY, Couto LB, et al (1999) Long-term correction of canine hemophilia B by gene transfer of blood coagulation factor IX mediated by adeno-associated viral vector. Nat Med 5: 56-63

29. Kay MA, Rothenberg S, Landen CN, Bellinger DA, Leland F, Toman C, Finegold M, Thompson AR, Read MS, Brinkhous KM (1993) In vivo gene therapy of hemophilia B: sustained partial correction in factor IX-deficient dogs. Science 262: 117-119

30. Kaiser J (2004) Gene therapy: side effects sideline hemophilia trial. Science 304: 1423b-1425b
31. Gura T (2001) Hemophilia. After a setback, gene therapy progresses... gingerly. Science 291: 1692-1697

32. George LA, Sullivan SK, Giermasz A, et al (2017) Hemophilia B gene therapy with a high-specific-activity factor IX variant. N Engl J Med 377: $2215-2227$

33. Rangarajan S, Walsh L, Lester W, Perry D1, Madan B1, Laffan M1, Yu H1, Vettermann C1, Pierce GF1, Wong WY1, Pasi KJ (2017) AAV5-factor VIII gene transfer in severe hemophilia A. N Engl J Med 377: 25192530

34. Miesbach W, Meijer K, Coppens M, et al (2018) Gene therapy with adeno-associated virus vector 5-human factor IX in adults with hemophilia B. Blood 131: 1022-1031

35. Simioni P, Tormene D, Tognin G, Gavasso S, Bulato C, Iacobelli NP, Finn JD, Spiezia L, Radu C, Arruda VR (2009) X-Linked thrombophilia with a mutant factor IX (Factor IX Padua). N Engl J Med 361: 1671-1675

36. Herzog RW (2017) Complexity of immune responses to AAV transgene products - Example of factor IX. Cell Immunol pii: S00088749(17)30080-1

37. Nathwani AC, Tuddenham EGD, Rangarajan S, et al (2011) Adenovirus-associated virus vector-mediated gene transfer in hemophilia B. N Engl J Med 365: 2357-65

38. Keeler GD, Markusic DM, Hoffman BE (2017) Liver induced transgene tolerance with AAV vectors. Cell Immunol pii: S0008-8749(17)30221-6

39. Gilbert L, Rollins L, Hilmes M, Luo Y, Gailani D, Debaun MR, Sidonio RF (2014) Haemophilia A carriers demonstrate pathological and radiological evidence of structural joint changes. Haemophilia 20: e426-e429

40. Iorio A, Skinner MW, Clearfield E, Messner D, Pierce GF, Witkop M, Tunis S, coreHEM panel (2018) Core outcome set for gene therapy in haemophilia: Results of the coreHEM multistakeholder project. Haemophilia in press

\title{
Gene therapy of haemophilia - has the cure come within reach?
}

\author{
Radosław Kaczmarek
}

Department of Immunochemistry, Hirszfeld Institute of Immunology and Experimental Therapy, Polish Academy of Sciences, 12 Weigla St., 53-114 Wroclaw, Poland

e-mail: radoslaw.kaczmarek@iitd.pan.wroc.pl

Key words: haemophilia, gene therapy, coagulation factor VIII, coagulation factor IX

\begin{abstract}
Haemophilia is a bleeding disorder (usually congenital) caused by the deficiency of coagulation factor VIII (haemophilia A) or IX (haemophilia B). The genes encoding factors VIII and IX are located on the X chromosome, so the symptoms of congenital haemophilia A and B occur predominantly in males. Recurring episodes of spontaneous bleeding into joints are the main symptom of haemophilia, which lead to haemophilic artropathy. Historically, patients with haemophilia were treated with whole blood transfusions and then with blood plasma. The first big breakthrough in treatment efficacy was the advent of cryoprecipitate, followed by lyophilized coagulation factor concentrates, derived from plasma. The latter dramatically improved patients' quality of life and allowed for prophylactic self-infusions at home (home treatment). Since the 1990s, the standard treatment has also included recombinant coagulation factor concentrates derived from cell cultures. Today, the main challenges are the need for frequent venipunctures (factor concentrates must be administered intravenously) to maintain successful prophylaxis and emergence of neutralizing antibodies in response to exogenous coagulation factors. Several novel recombinant factors with extended half-life were approved in recent years. Clinical trials of other new technologies are ongoing. These are non-replacement therapies with different mechanisms of action (e.g. emicizumab, a bispecific antibody that mimics the procoagulant activity of factor VIII; fitusiran, siRNA downregulating antithrombin III) and gene therapies using AAV vectors.
\end{abstract}

